\title{
An evaluation of the customer service in supermarkets in Pretoria East, Tshwane Metropolis, South Africa
}

\author{
Nadene J MM Marx and Alet C Erasmus
}

\section{Opsomming}

Verbruikerstevredenheid word vandag op meer as bloot net die gehalte van produkte gebaseer - veral die diens wat in die kleinhandelomgewing gelewer word, word baie belangrik geag. Omdat die produkte op die winkelrakke dikwels oorwegend dieselfde is, is dienslewering uiteindelik die enigste manier waarop een handelaar homself van ' $n$ ander kan onderskei. Ongelukkig kon min navorsing gevind word wat aandui hoe die harte en beursies van verbruikers in belang van handelaarslojaliteit gewen kan word. Bestaande navorsing spreek meestal enkele, baie spesifieke elemente van klantediens aan, veral in terme van hoe dit aankoopgedrag en voortgesette ondersteuning van handelaars sal beïnvloed.

In hierdie navorsing is veronderstel dat kleinhandelaars verbruikers se lojaliteit kon wen indien die dienskwaliteit in belang van groter verbruikerstevredenheid verbeter kon word. Deur hierdie navorsing is gepoog om vas te stel hoe verbruikers die klantediens in Suid-Afrikaanse supermarkte beoordeel sodat voorstelle gemaak kon word ten opsigte van die verbetering van spesifieke elemente van klantediens. Die elemente van dienskwaliteit wat afsonderlik of gesamentlik tot verbruikers se voorkeur vir sekere supermarkte (in terme van gereelde en herhaalde aankope) bydra, is dus ondersoek.

Teorie en besprekings is binne die sisteembenadering aangebied omdat dit die geleentheid gebied het om die samehang, onderlinge belang en afhanklikheid van die onderskeie elemente van klantediens sinvol te bespreek. Die kognitiewe perspektief is betrek ter wille van ' $n$ bespreking van verbruikers se interpretasie van winkeldiens.

' $n$ Gerieflikheidssteekproef is deur middel van die sneeubaltegniek in Pretoria-Oos, in die geografiese metropool van Tshwane gewerf. Die area is gekies omdat daar verskeie supermarkte binne 'n klein radius geleë is wat dit vir verbruikers moontlik maak om verskillende supermarkte te ondersteun. Deelnemers moes in die area woonatig wees en/of daar inkopies gedoen het en moes ouer as 25 jaar wees. Geen vereiste is ten opsigte van ras of geslag gestel nie. ' $n$ Kwantitatiewe data-opname tegniek is gebruik (vraelysopname), hoewel 'n kwalitatiewe tegniek (fokusgroepgesprekke) vooraf gebruik is om die inhoud en bewoording van die vraelys te valideer - veral om alledaagse terminologie en byko- mende konstrukte te identifiseer wat moonlik nie uit die teorie duidelik geblyk het nie.

Resultate het getoon dat verbruikers gereeld by verskillende supermarkte in die area koop en dat hulle die diens van sommige supermarkte betekenisvol beter ag as diè van ander. Die elemente van klantediens wat groter kritiek uitgelok het, het meestal met personeel verwante eienskappe en met prosesse verband gehou. Hoewel prys belangrik was in terme van gereelde aankope, was verbruikers meer krities ten opsigte van hoe hulle deur personeel hanteer word en ekstra moeite wat handelaars doen om die aankoopgeleentheid sonder voorval te laat verloop. Twee supermarkgroepe is betekenisvol swakker as die ander vier wat in die studie ingesluit is, beoordeel. ' $n$ Interessante bevinding was dat die supermark wat die swakste beoordeel is, gedurende die voorafgaande boekjaar die meeste aan advertensie spandeer het. Die aanbeveling is dat hierdie geld beter aangewend kan word in belang van klantediens, veral in terme van die opleiding van personeel.

- Ms NJMM Marx

Department of Consumer Science

University of Pretoria

- Dr AC Erasmus

Department of Consumer Science

University of Pretoria 


\section{INTRODUCTION AND MOTIVATION FOR THE RESEARCH}

Problems with customer service (CS) are not unique to the South African context. The American Customer Satisfaction Index (University of Michigan in Gowan et al, 2001:278) indicates that customers' satisfaction with the service in the retail environment in the USA declined by 12 percent between 1996 and 2001. Howardell (2003) explains that customers want it all and they want it now and warns that if a particular retailer fails to provide what customers want, it will not be difficult for these customers to find another that can. As a consequence, the majority of customers shop hop to overcome unsatisfactorily customer service (Woodruff, 1997; Webster, 1994).

Research on this topic to date has mainly focused on products and production processes rather than on services per se, and most of what has been published refers to first-world experiences (Calif, 2001; Dawson, 2000; Erdem et al, 1999). The relevance of excellent CS to the survival of a company in a competitive marketplace has been discussed repeatedly (e.g. see Du Vázqueza et al 2003; Malan, 2003; Nielsen, 2002; Seybold, 2001; Woodruff, 1997) and there seems to be no doubt that $\mathrm{CS}$ is vital to service quality (Bennett \& Rundle-Thiele, 2004; Cronin et al, 2000; Spreng \& Mackoy, 1996). In fact, CS is supposed to add memorable and satisfactory value to a purchasing experience and to boost customer satisfaction as well as adding to an overall perception of service quality with a prospect of customer loyalty. The literature however does admit that earlier attempts to identify what keeps retailer shoppers loyal to a store have not been very successful. In conjunction with imprecise definitions of CS, confusion about the meaning and relatedness of constructs pertaining to commendable CS still cause widespread confusion (Winstead, 1997).

In order to deliver service quality in a specific context (e.g. supermarkets), CS per se has to be clarified both in terms of its individual elements/attributes and also their collective contribution towards customer satisfaction and, ultimately, store loyalty. An inspection of existing publications indicates that very specific individual attributes of CS (e.g. price; product variety and quality; store personnel; place and physical environment; promotions) have almost been over researched over the years in terms of their role in promoting store loyalty and influencing buyers' behaviour. Little evidence, however, is available to help us understand and describe the collective contribution of the elements of CS towards service quality. Also, apart from some research in Asian countries (Kim et al, 2002), most research into consumer behaviour relies on theoretical frameworks developed in sophisticated Western societies, with little known about how consumers in different countries and cultural backgrounds evaluate and anticipate CS (Du Plessis et al, 1995:169).

\section{RESEARCH PROBLEM}

Certain supermarket conglomerates have become household names in South Africa; we all patronise Pick 'n Pay, Spar, Checkers, Shoprite, OK the supermarket departments in Woolworths or Woolworths Foods when we do our grocery shopping. Gone are the days when we enjoyed the personal assistance of the friendly grocer on the corner of the street. These retailers have since made way for retail giants whose shops occupy hundreds of square metres and draw thousands of customers, pushing gigantic trolleys through long alleys in seemingly never-ending shopping malls. These supermarkets are furthermore often located within close proximity of one another, although they stock more or less the same goods, which suggests that a difference in their CS differentiates them in terms of service quality and ultimately also customers' store loyalty (Bell, 2003). The term CS, however, refers to an assortment of attributes that collectively constitute $\mathrm{CS}$ as a collective phenomenon. Any single positive attribute of CS, e.g. competitive prices or product assortment, might therefore not necessarily ensure consumer satisfaction or store loyalty. The intangibility of CS makes it particularly difficult for both retailers and customers to objectively evaluate (Levy \& Weitz, 2001:176, 586, 587). CS assessed in terms of service quality can therefore vary considerably from one store to the next and from one customer to another.

\section{RESEARCH OBJECTIVE}

The main objective with this research project was to evaluate the CS in South African supermarkets in the eastern suburbs of Tshwane. This area probably represents the ultimate of what the respective supermarkets offer in terms of supermarket shopping in South Africa at present, considering the demographic profile and socio-economic characteristics of the area. To identify the shortcomings that could be amended to improve consumers' satisfaction with CS, this study aims to provide, based on consumers' experiences of well-known supermarkets, firstly a narrative of consumers' satisfaction with CS as a whole, and secondly a description of their satisfaction with various attributes of specific elements of CS.

\section{CONCEPTUAL BACKGROUND}

\section{Supermarkets}

A supermarket is defined as any large, departmentalised retail store that primarily sells food products and groceries (Marshall \& Nielson, 2001). In the South African context, OK, Spar, Pick 'n Pay, Checkers and Shoprite fall into this category. A department store refers to a large retail unit with an extensive assortment (variety and range) of goods and services that are organised into separate departments that may include a foods and grocery section (Thang \& Tan, 2003), e.g. Woolworths. The focus group discussions conducted as part of this study indicate that consum- 
ers do not necessarily make this distinction. All the retailers listed above, as well as their hyper stores and smaller foods outlets were therefore included in this study's definition of "supermarket".

\section{Customer service}

Customer service (CS) refers to the combination of activities offered by retailers. If taken seriously, CS is presented with the intention of enhancing service quality, so that customers perceive the shopping experience as more pleasant and even rewarding (Howardell, 2003; Levy \& Weitz, 2001: 586, 587; Woodruff, 1997; Zikmund \& d'Admico, 2001:331). For the purpose of this study, CS is interpreted in terms of the four elements of the marketing mix namely, product, place, price, promotion, and three additional elements (added to the marketing mix by Booms \& Bitner, 1981), namely people, processes and physical evidence, to include the widest possible spread of possible influencing variables. CS is further considered as a means-to-end process where all the interactions/"moments of truth" are interrelated in terms of a total experience. It is assumed that good CS revolves around getting all the elements of the process right to prevent failure because of an apparent weakest link (Rhee \& Bell, 2002; Woodruff, 1997).

Customer service in terms of customer satisfaction From a business point of view, customer satisfaction implies always doing the right things right (Levy \& Weitz, 2001:586; Woodruff, 1997). Customer satisfaction is essential for the survival of retailers because it enhances repeat purchase behaviour and contributes to positive word-of-mouth communication and the breeding of so-called customer advocates (Malan, 2003). Process definitions of satisfaction are based on the expectancy disconfirmation paradigm that proposes that confirmation and positive disconfirmation generally result in satisfaction, as opposed to negative disconfirmation that leads to dissatisfaction. Evaluation is generally done within a framework of expectations to conclude a desires congruency (with what was expected), and either positive or negative disconfirmation (Spreng \& Mackoy, 1996); this can result after single, or brief encounters. Satisfaction can also refer to a state of fulfilment that involves reinforcement and arousal over time; this requires repetitive exposure and experience (Yi, 1990 in lacobucci et al, 1995). Consumer satisfaction influences a consumer's motives and attitudes during subsequent consumer decisions, e.g. to patronise a specific supermarket or not (Du Plessis et al, 1990 in Erasmus \& Donoghue, 1998).

Customer service in terms of store loyalty Store loyalty occurs when a customer intentionally chooses one store over others, irrespective of the offerings at the other stores (Levy \& Weitz, 2001:152). Consumer satisfaction however does not necessarily result in store loyalty; consumers who are highly satisfied with a store's CS may for example still not be loyal. Wellmanaged customer retention programs that are communication- and tactics-driven and which strive to improve CS are generally used to encourage custom- ers' loyalty in a competitive market place (Malan, 2003).

Customer service as a collective phenomenon CS per se refers to an assortment of attributes that collectively represent the service. The systems theory provides a useful vehicle for incorporating the various elements of CS, i.e. discussing an experience as a whole (Spreng \& Mackoy, 1996; Whitchurch \& Constantine, 1993:328). The systems theory enables a study of the various elements of CS but acknowledges the sequence, relationship and interdependency of the fundamental elements of CS. The elements of CS comprise all the external factors that incite the consumer's mind (Thang \& Tan, 2003). The interpretation of the individual elements of CS is considered a cognitive activity; it involves interpretation within established schemata in memory that are based on existing knowledge structures (Spears \& Gregoire, 2003:2). Consumers can therefore be postulated to convert stimuli (elements of CS) into meaningful information and then apply this consciously or subconsciously when they comprehend the environment before making a judgement (Thang \& Tan, 2003). Upon entering a supermarket, consumers therefore rely on internal resources to comprehend the situation and to guide their decision-making processes (Belch \& Belch, 1998:104). The systems theory further postulates that when one element (e.g. price) changes, a consumer's interpretation of the other elements of CS (e.g. product availability) as positive/negative will also change. This occurs on a subliminal level (Schiffman \& Kanuk, 2000:172-179). Wholeness is another important characteristic of a systems approach; the output of the system (e.g. superior CS) may not necessarily be derived from elements of CS considered in isolation (e.g. assuming that competitive price would be a precondition for superior CS). Of greater importance is the collective contribution (priority and hierarchy) of the composite elements of CS in terms of service quality and store loyalty (Whitchurch \& Constantine, 1993:325, 328). Although consumers do judge and comment on elements independently, their collective contribution eventually determines the interpretation of service quality/outcome.

Within the systems theory, equifinality refers to the phenomenon where a certain level of CS (output) may be achieved via different routes, e.g. a combination of lower prices and higher product availability at the cost of store design and layout, as opposed to higher prices and elaborate product ranges or convenient store design. The compensatory rule of consumer decision-making applies (Schiffman \& Kanuk, 2000:452); a consumer evaluates CS and allocates relative weights to elements of $\mathrm{CS}$ in terms of their perceived importance in a specific context to establish a final CS score for each store visited. The store with the highest score will thus probably represent the preferred one. Two stores might thus earn the same total score although scores for individual service elements might differ considerably; both will then provide "good CS", but via different routes. On the other hand, a store with a high score, which might appear 
acceptable, may still fail to attract customers due to an unacceptable minimum condition. This explains the contribution of each element of CS in terms of eventual acceptable CS. Customers will patronize a retailer when the perceived CS meets or exceeds their expectations (Levy \& Weitz, 2001:152, 587). The post-purchase reaction to purchase behaviour that is typical of a dynamic system affects subsequent purchases by creating an internal frame of reference that determines future evaluation. If the consumer is satisfied with the consequences of a purchase experience, the probability of repeat purchase behaviour increases. Feedback is therefore of utmost importance in searching for ways to improve customer service (Spears \& Gregoire, 2003:2,3).

Individual elements/attributes of customer service Consumers generally look for tangible evidence (contextual cues) of what they are about to experience in a given service encounter, which is intangible (Bitner, 1994). The elements of CS that may contribute to service quality are now briefly discussed in terms of the traditional variables of the marketing mix (as discussed by McCarthy in 1960), and including the expanded version discussed by Booms and Bitner (1981), that acknowledges certain additional contextual cues (Woodruff, 1997:142).

Product This refers to the merchandise assortment as need-satisfying utilities (Zikmund \& d'Admico, 2001:654), e.g. a supermarket's product offerings in terms of range, quality and availability, and also includes packaging, because this eventually also contributes to the image of the store through its effect on shelf life, product image, communication of product information and affordability.

Place/physical surrounding The store itself has thus become a fertile opportunity for market differentiation to the extent that store image (e.g. a safe, beautiful, hygienic environment) may be an important antecedent of store satisfaction and store loyalty (Levy \& Weitz, 2001:176, 555; Zikmund \& d'Admico, 2001:11-12). It has been reported that customers nowadays desire hedonic experiences (multi-sensory, fantasy and emotive aspects of consumption) that extend beyond the purpose of acquiring merchandise (Arnold, 2003; Holbrook \& Hirschman, 1982; Thang \& Tan, 2003). Criteria for success may even be aesthetic in nature (Holbrook \& Hirschman, 1982; Malan, 2003). Retailers therefore have to determine how much their target market will be willing to pay for atmosphere and physical resources such as convenient parking facilities (Zikmund \& d'Admico, 2001:11-12).

Price The amount of money that is exchanged for the satisfaction of a need is generally considered acceptable if the value of the product purchased is perceived to be equal to, or exceeding the amount paid. Irrational evaluation of price occurs when price is used as an indication of quality. Pricing strategies are often used to sway buyer decisions because most consumers are ill equipped to guard against them (Assael, 1993:650; Zikmund \& d'Admico, 2001:654). Depending on the importance of price in a consumers' inter- pretation of CS, price can thus be a very important determinant of a consumer's patronage of a specific store.

Promotion All forms of marketing communication, in written, oral, auditory and/or visual format, used to draw attention to a store's offerings influence customers' decision to patronize the store or not (Zikmund \& d'Admico, 2001:655). Vast amounts of money are spent annually to promote businesses; four of the prominent six supermarkets in South Africa were listed in the top ten advertisers in 2004/5.

Salespeople and personnel With respect to selling orientation/customer orientation, salespeople and other personnel significantly influence customers' satisfaction with stores, products and manufacturers. Efforts towards product development and promotion are apparently often negated by the poor performance of salespeople (Goff et al, 1997; Sharma \& Levy, 1995). A good customer- salesperson relationship contributes to a pleasant shopping experience (Reynolds \& Beatty, 1999) and reduces risk perception, especially during the final stages of the decisionmaking process (Solomon, 1986). A customeroriented approach that signifies empathy, expertise and competence enhances customer satisfaction and store loyalty (Clopton et al, 2001).

Processes All the procedures, mechanisms and flows of activity e.g. handling complaints, ensuring dependability, and providing credit facilities, exchange policies and guarantees make up the process of attracting and retaining customers. Customers expect retailers to be supportive and so any service/ mechanism that suggests empathy and understanding will enhance consumer satisfaction (Dabholkar et al, 1994; Du Vázqueza et al, 2003).

Retail policies All stores have specific strategies to attract and retain customers (Du Vázqueza et al, 2003). These policies become very complex in their application in a supermarket that serves customers with different lifestyles from different socio-economic and cultural backgrounds, as opposed to a shop that serves a smaller, more homogeneous market. Unfortunately the needs of a generalized European or American consumer are often accepted as the norm in studies of supply products in retail, even in third-world countries (Du Plessis et al., 1995:169).

\section{RESEARCH METHOD}

\section{Research style}

The study was conducted using a quantitative methodological paradigm but includes quantitative as well as qualitative data collection techniques to enhance validity and reliability (Babbie \& Mouton, 1998:291, 292). The study was cross-sectional in nature. Data was collected in August 2004, with the assistance of four trained field workers who distributed and collected questionnaires in specific areas. 


\section{Sample and sampling}

Participants were recruited in the eastern suburbs of Pretoria. This area, which has a relatively high socioeconomic status in the Tshwane metropole, was chosen based on reports that consumers with higher discretionary incomes are more aware of their consumer rights and thus generally have a greater intolerance of poor CS (Arnold, 2003; Samson \& Little, 1993:390) and can afford to travel to different supermarkets to find a pleasurable shopping experience (Nielsen, 2002). Two assumptions were made in terms of the selection of the geographical area: firstly, that retailers present their best CS offering in more affluent communities and secondly, that the problems found in such an area probably also exist and may even be more intense in poorer areas, so the chosen sample area represents the best- rather than the worst-case scenario. Because of time and financial constraints and because of the recommendation of other researchers, snowball sampling (chain referral) was used to recruit participants (Areni, 2003; Leong et al, 1997). Participants were recruited in a structured manner to include a good distribution of participants from the various suburbs in the target area (Neuman, 1997:204). Any willing individuals older than 25 years, irrespective of gender, who managed or co-managed their own household were included. They were expected to have had at least six personal buying experiences at two or more of the well-known supermarkets during the preceding three months (Thang \& Tan, 2003).

\section{Data collection}

Phase 1: Focus group discussions Two focus group discussions were held as an initial data collection phase to verify the theoretical content and wording of the questionnaire, to ensure inclusion of familiar concepts and everyday language, and avoidance of theory that primarily reflects first-world experiences (McQuarrie \& McIntyre, 1988). Participants were limited to ten per discussion group to allow enough time for each participant to express his/her views in the limited time. Simultaneous participation of friends, spouses and family was not allowed (Babbie \& Mouton, 1998:292; Cook, 1982). Participants were invited, knowing that the study was concerned with CS in supermarkets. No reference was made to any particular stores or specific characteristics of CS. Discussions evolved from general to specific; open-ended questions were used to encourage discussions of specific personal experiences (Garrison et al, 1999). Discussions were tape-recorded with the consent of the participants, to enable accurate transcriptions (Babbie \& Mouton, 1998:292). The following represent examples of the prompts used during the discussions:

- Do you prefer certain supermarkets and avoid others when doing your grocery shopping? Explain.

- What do you expect of a supermarket before you will give it your continual support?

- Do the supermarkets in your area provide the same service?

Phase 2: Structured questionnaire The structured questionnaire distributed as the main data-collection instrument predominantly contained closed questions, which were finalized in terms of wording and content after interpretation of the focus group discussions. The questionnaire consisted of six sections: (A) Demographics and general buyer behavior (e.g. How frequently have you shopped at each of the following supermarkets in the past three months? Who does the grocery shopping for your household?; How frequently do they do it?); (B) Judgment of the importance of the attributes of CS (using a five-point scale to score 34 statements e.g. How important do you regard the following in your judgement of the service of a supermarket?); (C) Listing of intolerable attributes of CS (involved an open-ended question that enabled cross validation (Zikmund \& D'Amico, 2001:146; Leong et al, 1997); (D) An evaluation of well known supermarkets (using a five-point scale to score statements e.g. Indicate your view of the customer service of the supermarket/s where you generally do your shopping); (E) A rating of satisfaction with specific attributes of CS (using a five-point scale to score 33 attributes e.g. How satisfied are you in general with the following aspects of customer service of the supermarket/s where you generally do your shopping?); and (F) Willingness to recommend supermarkets (referring to all the supermarkets in the area with questions such as Would you recommend the following supermarkets to your best friend for regular purchases?).

Four trained field workers (Masters-degree students) assisted with the distribution and collection of questionnaires in the selected area on a drop-and-collectlater basis. Questionnaires were collected at an appointed time within 48 hours of drop-off, and were returned in sealed envelopes. Of the 500 questionnaires that were distributed in 48 suburbs over a 14 day period during August 2004, 386 were successfully retrieved by the deadline.

\section{QUALITY OF DATA}

Various precautions were taken during the research process to limit error and to enhance the validity and reliability of data.

\section{Validity}

Theoretical validity To enhance the theoretical validity of this study, all the key concepts pertaining to CS, store loyalty and consumer satisfaction were identified through a thorough literature review before the compilation of the questionnaire. This was further supported by focus group discussions during which special attention was given to the language used by participants to refer to specific theoretical concepts so that nothing was overlooked, incorrectly labelled, or left vague or complex.

Construct validity More than one method was used to identify relevant constructs and appropriate terminology, so that construct validity was enhanced. A simple Likert-type scale was used as the main means of measurement in the questionnaire, based on its success in similar studies in the past and the 
ease it brings to the interpretation of lengthy questionnaires such as this one (Danaher, 1997).

Inferential validity The assistance of a professional statistician ensured that data was correctly analysed, and that statistical procedures were chosen in accordance with the objectives of the study.

\section{Sampling error}

To reduce error in terms of the relatively large sample population, sampling was done according to predetermined criteria. The sample was compared to the population profile of the Tshwane metropole. Only eager and willing participants were included so that it could be assumed that their responses are truthful.

\section{Reliability}

The key criterion for validity in data collection is reliability (Mouton, 1996:156, 157), which was addressed by using a combination of data-collection methods (Plug et al, 1997:43, 108) educe possible errors during the focus groups discussions (Katzer, 1982:64), time and location of discussions were arranged to suit participants; the discussions were held in a neutral environment to enhance open communication; and a maximum of ten willing individuals was included to allow each participant enough time to voice his/her individual feelings, perceptions and experiences.

Possible sources of error during the implementation of the questionnaires were addressed through clear statement of the purpose of the survey; an indication of the researcher's affiliation; and a promise of confidentiality. The length of the questionnaire was limited and it was pre-tested before implementation. Only trained assistants conducted the surveys and only willing individuals were included.

\section{DATA ANALYSIS}

This study aims to examine the CS of South African supermarkets in general and never intended to discriminate against or to favour any of the supermar- kets. Because of the sensitive nature of this research, the identities of the supermarkets and department stores that were investigated, namely Checkers, Checkers Hyper, Pick 'n Pay, Pick 'n Pay Hyper, Spar, Super Spar, OK, Woolworths and Woolworths Foods were thus protected by the use of codes A, B, C, D and $E$ (these do not coincide with the order of the listed stores) in the research report. $\mathrm{Aa}, \mathrm{Bb}, \mathrm{Cc}$ etc, refer to the hyper stores and/or the food versions of the relevant supermarkets.

\section{Focus group discussions}

Immediately after each session the recordings made during a focus group discussion were transcribed and cross-checked by the researchers. Content analysis, open coding and axial coding were done to confirm and identify constructs and concepts that were already contained in the questionnaire or new ones that had to be taken into consideration. Attention was also given to common language used in the discussions, and the questionnaire adapted accordingly (Babbie \& Mouton, 1998:292).

\section{Questionnaire}

Descriptive and inferential statistics suited to the specific objectives of the study were implemented. Linear regression was carried out and Pearson correlation coefficients calculated to determine whether the three identified elements of CS would be useful to predict satisfaction with CS and willingness to recommend supermarkets to others.

\section{RESULTS}

\section{Profile of participants}

Of the 386 useful questionnaires that were collected, 99 were completed by male and 287 by female participants.

\section{Buying habits}

Patronage of specific supermarkets Table 1 indi-

TABLE 1: $\quad$ PARTICIPANTS' PATRONAGE OF DIFFERENT SUPERMARKETS ( $\mathrm{N}=386$ )

\begin{tabular}{|c|c|c|c|c|c|}
\hline Frequency of shopping & 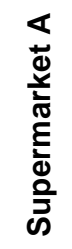 & 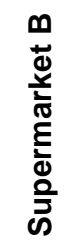 & 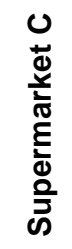 & 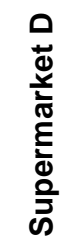 & 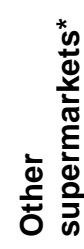 \\
\hline At least once a week & 109 & 136 & 158 & 76 & 21 \\
\hline Max 2-3 times a month & 91 & 122 & 84 & 72 & 15 \\
\hline Max once a week & 33 & 49 & 45 & 21 & 4 \\
\hline Once & 63 & 48 & 41 & 75 & 17 \\
\hline Never & 45 & 12 & 17 & 85 & 55 \\
\hline Total & 341 & 367 & 345 & 339 & 112 \\
\hline
\end{tabular}

* "Other" includes supermarket $\mathrm{E}$ as well as convenience stores at garages 
cates that supermarket $B$ seems to be the most frequently visited in general and that $B$ and $C$ are most frequently visited on a weekly basis. Supermarket $D$ is apparently patronized less frequently in general, and is never patronised by $85(22 \%)$ of the participants. During focus group discussions some participants mentioned that although they would have preferred to do the majority of their grocery shopping at A, they could not afford to do so and generally only go there for fill-in shopping.

Family members' involvement in supermarket shopping The percentages in Table 2 were calculated in terms of the larger sample. The largest percentage (mostly women) apparently does grocery shopping on a monthly basis; $14,6 \%$ of husbands/ partners of participants shop weekly, and children's involvement in terms of grocery shopping for the household is not really worth mentioning. During focus group discussions participants indicated that they generally stop at conveniently located supermarkets on their way home from work for fill-in shopping but that they intentionally go to their preferred supermarkets on a weekly basis to do major shopping. Children were not specifically mentioned during these discussions.

\section{Importance of individual elements of CS with regard to service quality}

As indicated in focus group discussion The focus group discussions generally confirmed the theoretical content of the questionnaire. Certain additional constructs that appeared to be more typical of the South African situation however were mentioned and accommodated in the questionnaire, e.g. safety aspects such as area or personal safety in the stores; poor service from salespeople; and inefficient personnel.

As indicated in the questionnaires In Section B of the questionnaire, participants had to rate 34 attributes of CS in terms of importance of contribution to service levels in supermarkets (Table 3 ). More than $90 \%$ of the participants (more than 347 out of 386 ) rated 19 out of the 34 listed attributes as either important or very important. Only two attributes, namely regular promotions and demonstrations in store and access to internet shopping were rated as less important or unimportant by more than $30 \%$ (116 and more) of participants.

In terms of the attributes considered very important, those mentioned by more than $80 \%$ (309 and more out of 386) of the participants were: place-related (a clean store); and product-related (strict control over the freshness of products). The same indication was given in focus group discussions where the cleanliness of stores was discussed with enthusiasm. Cleanliness/perceived hygiene was indicated as a reason why consumers prefer to patronise supermarket $A$, the only store that was apparently perceived as a clean store.

Attributes mentioned as very important by $70-79 \%$ $(n=270-308)$ of participants were: place-related (store layout); product-related (products of excellent quality) and process-related (minimum waiting time at cashiers).

Attributes mentioned as very important by $60-69 \%$ $(n=231-269)$ of participants were: place-related (clear signage in store; safety/security); personnel-related (enthusiastic staff; knowledgeable staff); and processrelated (clean trolleys; availability of credit card facilities).

Attributes mentioned as very important by $50-59 \%$ $(n=193-230)$ of participants were: place-related (easy access to the parking area; well located parking bays; location of the store in a safe area; practical shelf layout; convenient location of the store); product-related (large product variety; availability of new products); personnel/process-related (efficient staff assistance; approachable managers); and process-related (provision of good quality plastic bags for shoppers).

The aspects considered least important were in-store demonstrations and access to internet shopping. The latter, although a new tendency in supermarket shopping world-wide, is currently apparently not a local priority yet.

\section{Satisfaction with specific attributes of CS of su- permarkets patronized by respondents}

Participants indicated their satisfaction with specific attributes of CS (specific denominators of the elements of CS drawn from the literature as well as the focus group interviews) of the supermarkets they patronize in section $E$ of the questionnaire. This was used to transliterate all the attributes of CS that were rated highly or poorly, in terms of elements of CS. Table 4 indicates participants' satisfaction with the various attributes of CS with reference to the "supermarket/s that they patronize on a regular basis".

In terms of participants' satisfaction with specific attributes of CS (a summation of satisfied and highly satis-

TABLE 2: $\quad$ FAMILY MEMBERS' INVOLVEMENT IN SUPERMARKET SHOPPING (N=386)

\begin{tabular}{|l|c|c|c|c|c|c|c|c|}
\hline & \multicolumn{2}{|c|}{$\begin{array}{c}\text { Participant } \\
\text { (self) }\end{array}$} & \multicolumn{2}{c|}{$\begin{array}{c}\text { Husband/ wifel } \\
\text { partner }\end{array}$} & \multicolumn{2}{c|}{ Children } & \multicolumn{2}{c|}{ Other } \\
\hline Frequency & $\mathbf{N}$ & $\%$ & $\mathbf{N}$ & $\%$ & $\mathbf{N}$ & $\%$ & $\mathbf{N}$ & $\%$ \\
\hline Monthly $\mathrm{n}=122$ & 89 & 23,0 & 28 & 7,3 & 8 & 2,0 & 7 & 1,8 \\
\hline Weekly $\mathrm{n}=245$ & 18 & 4,6 & 52 & 14,6 & 4 & 1,0 & 14 & 3,6 \\
\hline Daily $\mathrm{n}=84$ & 59 & 15,2 & 21 & 5,4 & 3 & 0,7 & 1 & 0,2 \\
\hline Occasionally $\mathrm{n}=106$ & 21 & 5,4 & 49 & 12,6 & 34 & 0,9 & 2 & 0,5 \\
\hline
\end{tabular}


TABLE 3: IMPORTANCE OF VARIOUS ATTRIBUTES OF CS IN SUPERMARKETS IN GENERAL ( $N=386)$

\begin{tabular}{|c|c|c|c|c|c|c|}
\hline Attributes of CS & 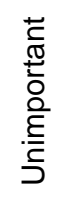 & 蒙 & 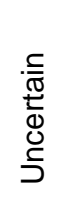 & 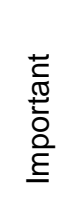 & 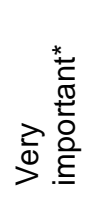 & $\begin{array}{l}\text { D. } \\
\text {. } \\
\stackrel{\mathscr{W}}{\Sigma}\end{array}$ \\
\hline Clean store & 0 & 1 & 4 & 51 & 326 & 4 \\
\hline Strict control of freshness of products & 0 & 4 & 4 & 47 & 325 & 6 \\
\hline Products of excellent quality & 0 & 2 & 3 & 79 & 301 & 1 \\
\hline Short queues at the cashiers/minimum waiting time & 1 & 5 & 9 & 75 & 296 & 0 \\
\hline Store layout & 0 & 2 & 7 & 105 & 270 & 2 \\
\hline Clean trolleys & 0 & 9 & 6 & 125 & 245 & 1 \\
\hline Friendly, enthusiastic staff assistance & 2 & 4 & 15 & 123 & 242 & 0 \\
\hline Clear/visible signage to indicate product location & 1 & 7 & 19 & 116 & 241 & 2 \\
\hline Security in the store & 1 & 14 & 29 & 102 & 235 & 5 \\
\hline Availability of credit/debit card facilities/in-store ATM & 7 & 21 & 21 & 103 & 230 & 4 \\
\hline Well trained / knowledgeable staff & 1 & 14 & 19 & 121 & 230 & 1 \\
\hline Efficient staff assistance & 2 & 10 & 18 & 127 & 229 & 0 \\
\hline Easy access to parking area from road & 1 & 10 & 20 & 123 & 227 & 5 \\
\hline Well located parking bays & 1 & 6 & 11 & 138 & 224 & 6 \\
\hline Practical, logical shelf layout & 0 & 9 & 15 & 138 & 223 & 1 \\
\hline Store located in a safe place & 0 & 4 & 12 & 145 & 222 & 3 \\
\hline Large product variety & 1 & 4 & 17 & 141 & 221 & 2 \\
\hline Managers that are approachable & 5 & 26 & 23 & 117 & 213 & 2 \\
\hline Store conveniently located & 0 & 9 & 16 & 152 & 206 & 3 \\
\hline Availability of new products & 2 & 15 & 20 & 142 & 205 & 2 \\
\hline Strong plastic carry bags & 16 & 28 & 29 & 109 & 200 & 4 \\
\hline Comfortable in-store temperature & 2 & 7 & 17 & 177 & 183 & 0 \\
\hline Pleasant store atmosphere & 0 & 13 & 19 & 179 & 173 & 2 \\
\hline Uniformly dressed staff & 4 & 34 & 39 & 146 & 163 & 0 \\
\hline Efficient packers at the cashiers & 4 & 37 & 28 & 164 & 150 & 3 \\
\hline Managers that show interest in client & 3 & 50 & 53 & 126 & 149 & 5 \\
\hline Aesthetically appealing in-store environment & 3 & 34 & 40 & 175 & 131 & 3 \\
\hline Lowest prices, cheapest products & 5 & 52 & 62 & 132 & 129 & 6 \\
\hline Provision of free plastic carry bags & 33 & 75 & 60 & 87 & 127 & 4 \\
\hline Bargains in store on a regular basis & 6 & 47 & 64 & 148 & 117 & 4 \\
\hline Regular advertising of store specials & 16 & 64 & 56 & 137 & 110 & 3 \\
\hline Modern appearance of store & 15 & 64 & 54 & 150 & 99 & 4 \\
\hline Regular promotions/demonstrations & 29 & 115 & 68 & 101 & 73 & 0 \\
\hline Access to internet shopping & 80 & 99 & 76 & 61 & 63 & 7 \\
\hline
\end{tabular}

Attributes are arranged in descending order according to the very important figures

fied figures), more than $75 \%$ of the participants were satisfied or highly satisfied with place-related attributes (in-store temperature: $85 \%$; in-store layout: $85 \%$; location of parking bays: $85 \%$; cleanliness of store: 85\%; store appearance: $85 \%$; convenience of store location: 97\%) and product-related attributes (quality of products: $85 \%)$.

Between 20\% $(n=77)$ and 30\% $(n=116)$ indicated that they were dissatisfied or highly dissatisfied with per- sonnel/process-related attributes (waiting time in queues: $27 \%$; knowledge of staff: $21 \%$; assistance of staff: $20 \%)$.

Between 10\% $(n=39)$ and 15\% $(n=58)$ indicated their discontent with personnel/process-related attributes (friendliness of staff: $12 \%$; assistance of managers: $13 \%$; in/efficiency of packers: $12 \%$; interest of the managers in the customers: 16\%); place-related attributes (security in the store: 11\%) and process- 
TABLE 4:

\begin{tabular}{|c|c|c|c|c|c|c|}
\hline Attribute of CS & 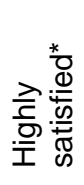 & 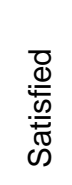 & $\begin{array}{l}\cdot \frac{5}{\pi} \\
\frac{T}{d} \\
0 \\
5 \\
5\end{array}$ & 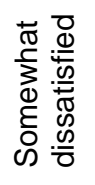 & 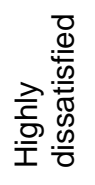 & $\begin{array}{l}\text { O } \\
\stackrel{\mathscr{D}}{\mathcal{N}} \\
\sum\end{array}$ \\
\hline Convenient location & 126 & 229 & 20 & 5 & 1 & 5 \\
\hline In-store credit \& debit card facilities, ATM & 125 & 189 & 40 & 21 & 6 & 5 \\
\hline Quality of products & 122 & 219 & 28 & 13 & 0 & 4 \\
\hline Strong plastic carry bags & 107 & 185 & 60 & 21 & 7 & 6 \\
\hline Condition of the trolleys & 97 & 146 & 40 & 9 & 2 & 92 \\
\hline Cleanliness in stores & 96 & 230 & 30 & 22 & 4 & 4 \\
\hline Product variety & 93 & 220 & 41 & 23 & 4 & 5 \\
\hline Location of parking bays & 90 & 231 & 33 & 26 & 3 & 3 \\
\hline Signage of product location in the store & 87 & 191 & 68 & 33 & 4 & 3 \\
\hline Quality control of products & 83 & 219 & 58 & 21 & 1 & 4 \\
\hline Store layout & 83 & 244 & 37 & 16 & 2 & 4 \\
\hline Friendliness of staff & 81 & 182 & 71 & 38 & 10 & 4 \\
\hline In-store temperature & 80 & 248 & 38 & 14 & 1 & 5 \\
\hline Regular advertising of specials in the media & 80 & 185 & 86 & 26 & 4 & 5 \\
\hline Availability of new, interesting products & 78 & 197 & 79 & 26 & 2 & 4 \\
\hline Shelf layout & 75 & 223 & 53 & 27 & 2 & 6 \\
\hline Appearance of staff & 68 & 225 & 65 & 19 & 5 & 4 \\
\hline In-store security & 68 & 169 & 98 & 41 & 5 & 5 \\
\hline Quality of plastic carry bags & 65 & 195 & 77 & 37 & 5 & 7 \\
\hline Safety of the environment & 64 & 250 & 51 & 14 & 3 & 4 \\
\hline Store atmosphere & 64 & 222 & 74 & 18 & 0 & 8 \\
\hline Assistance of managers in the stores & 63 & 140 & 127 & 41 & 12 & 3 \\
\hline Modern stores & 63 & 241 & 65 & 12 & 1 & 4 \\
\hline Assistance and interest of managers & 61 & 152 & 108 & 49 & 11 & 5 \\
\hline Availability of bargains & 58 & 186 & 99 & 33 & 4 & 6 \\
\hline Efficiency of staff assistance to solve problems & 56 & 150 & 97 & 65 & 12 & 6 \\
\hline Appearance of stores inside & 54 & 271 & 47 & 9 & 1 & 4 \\
\hline Knowledge of staff & 54 & 166 & 81 & 69 & 12 & 4 \\
\hline Efficiency of packers at the cashiers & 51 & 195 & 82 & 40 & 14 & 4 \\
\hline In-store promotions/demonstrations & 51 & 177 & 117 & 36 & 1 & 4 \\
\hline Queues/waiting time at cashiers & 47 & 177 & 57 & 84 & 17 & 4 \\
\hline Access to internet shopping & 40 & 95 & 183 & 36 & 21 & 11 \\
\hline Prices & 39 & 217 & 70 & 41 & 12 & 7 \\
\hline
\end{tabular}

* Attributes are arranged in descending order according to the highly satisfied figures

SATISFACTION WITH ATTRIBUTES OF CS $(\mathrm{N}=386)$ 
related aspects (quality of plastic bags: $10 \%$; access to internet shopping: 15\%).

Customers mostly appeared to be dissatisfied with process-related aspects of CS where personnel were involved; a noteworthy percentage indicated that assistance and efficiency of both general frontline staff and management are not satisfactory. Participants generally appeared to be satisfied with product-related and place-related attributes, probably because most supermarkets stock the same goods, so that differentiation between the shops is based on other attributes.

\section{Intolerable attributes of customer service}

Section C contained an open-ended question where participants could mention any attribute, which they considered unacceptable to such a degree that it would cause them to leave a supermarket without buying anything. Table 5 reflects only those attributes of CS that were considered intolerable by more than $25 \%$ of the participants.

More than $50 \%$ of participants $(n>193)$ indicated that the following three attributes are intolerable in terms of customer service: personnel/process-related (rude or untrained staff); product-related (unavailability of products); and other reasons: (dirty trolleys). Attributes identified as intolerable by a noteworthy percentage of the sample (25\% to $50 \%$ ) were: personnel/processrelated (long queues at pay points); product-related (poor quality products); price-related (expensive products); and place-related (distance to the store/ location).

In retrospect, personnel- and process-related attributes are identified as the main contributors towards intolerable customer service, followed by productrelated issues, specifically quality-related attributes of products. Price (expensiveness) was mentioned by less than a third of the participants. These findings are consistent with the attributes and elements of CS scored as very important in supermarkets, which suggests that the participants' responses are valid and reliable, and indicates that the attributes mentioned should be considered relevant and worth taking notice of.

Evaluation of the various supermarkets
In Section D of the questionnaire, participants had to evaluate the CS of the various supermarkets in the geographical area where they generally do their shopping. The more positive a customer's interpretation of the CS at a specific supermarket, the greater the probability can be assumed to be that the customer will frequently visit that supermarket (Table 6).

In terms of excellent customer service, supermarkets $A$ and $A a$ were rated better than the other supermarkets. The supermarkets rated lowest, as least satisfied, were D, Dd and E; some participants even scored $\mathrm{E}$ as unacceptable. Noteworthy also is the number of participants who were uncertain of the CS in stores $\mathrm{D}$, Dd and $\mathrm{E}$; this probably indicates nonpatronage of these supermarkets (based on the formulation of the question). Satisfaction with supermarkets however does not necessarily ensure store patronage on a regular basis. During focus group interviews, participants indicated that they would have preferred to shop at A and Aa on a regular basis, but that regular patronage was simply unaffordable. This was confirmed in the responses to Section $C$ of the questionnaire where participants indicated that high prices cause them to leave a store without making a purchase (Table 5).

\section{Recommendation of specific supermarkets as an} indication of store loyalty

Based on participants' willingness to recommend supermarkets to others, supermarkets $A, A a, B, B b, C$ and $C c$ performed better than $D$ and $E$ (Table 7). A and Aa received the most "yes" votes while D and $E$ received the most "no" votes. D, Dd and E received many "uncertain" votes, which might reflect limited experience of these stores.

Aa was rated significantly better $(p=\leq 0,05)$ than all of the other supermarkets, while $A$ was rated significantly $(p=\leq 0,05)$ better than $B, C, C c, D, D d$ and $E$. Both $A$ and $A a$ were rated significantly better $(p=\leq 0,05)$ than $B b$. It must however be stressed that participants also cited $A$ and $A a$ as too expensive to patronise on a regular basis. When rating CS, participants were apparently not too concerned about higher prices but then admitted that they could not patronise these more expensive stores on a regular basis. No significant difference could be found between supermarkets $\mathrm{Bb}$ (a Hyper store), C and Cc. B, C and Cc

TABLE 6: $\quad$ PARTICIPANTS' EVALUATION OF THE VARIOUS SUPERMARKETS IN THE AREA WHERE THEY GENERALLY DO THEIR SHOPPING $(\mathrm{N}=386)$

\begin{tabular}{|l|c|c|c|c|c|}
\hline Supermarket & Excellent & Good & Uncertain & Poor & Unacceptable \\
\hline$A(n=307)$ & 151 & 113 & 33 & 9 & 1 \\
\hline$A a(n=311)$ & 181 & 96 & 24 & 8 & 2 \\
\hline$B(n=337)$ & 93 & 205 & 30 & 9 & 0 \\
\hline$B b(n=308)$ & 86 & 150 & 54 & 16 & 2 \\
\hline$C(n=334)$ & 84 & 180 & 51 & 17 & 2 \\
\hline$C c(n=294)$ & 97 & 146 & 40 & 9 & 2 \\
\hline$D(n=301)$ & 29 & 96 & 102 & 52 & 22 \\
\hline$D d(n=274)$ & 30 & 90 & 94 & 46 & 14 \\
\hline$E(n=224)$ & 6 & 25 & 110 & 54 & 29 \\
\hline
\end{tabular}


TABLE 7: $\quad$ WILLINGNESS TO RECOMMEND SUPERMARKETS

\begin{tabular}{|l|c|c|c|c|c|}
\hline Supermarket & Yes & No & Uncertain & Mean & Std dev \\
\hline$A(n=343)$ & 301 & 14 & 28 & 4,3159 & 0,80511 \\
\hline$A a(n=341)$ & 305 & 15 & 21 & 4,4340 & 0,7959 \\
\hline$B(n=341)$ & 280 & 15 & 36 & 3,9805 & 0,8501 \\
\hline$B(n=316)$ & 260 & 25 & 31 & 4,1243 & 0,6950 \\
\hline$C(n=314)$ & 254 & 15 & 45 & 3,9790 & 0,8143 \\
\hline Cc $(n=314)$ & 254 & 15 & 45 & 4,1122 & 0,7995 \\
\hline$D(n=294)$ & 78 & 134 & 82 & 3,2774 & 1,0322 \\
\hline$D d(n=309)$ & 146 & 93 & 70 & 3,1927 & 1,0658 \\
\hline$E(n=277)$ & 27 & 146 & 104 & 2,6652 & 0,0324 \\
\hline
\end{tabular}

were rated significantly better $(p=\leq 0,05)$ than $D, D d$ and $E$. We can thus conclude that $A$ and $A a$ are considered the best supermarkets although they are also considered too expensive to patronise regularly. Also, supermarket groups $D$ and $E$ have a lot to improve on in terms of their CS.

\section{CUSTOMER SERVICE EXPLAINED WITHIN THE SYSTEMS PERSPECTIVE}

Belch and Belch (1998:104) explain that external stimuli provoke consumer needs but that a consumer's interpretation of these stimuli (elements and attributes of CS) provokes the decision to buy or to refrain from buying. The cognitive perspective assumes that consumers long for consistency in their evaluation of CS on the basis of their individual perceptions. Consumers are influenced by elements and attributes of CS, but interpret/transform these cues in terms of a mental framework; cues are prioritised and evaluated in terms of the output that will best serve their needs. The lexicographic decision rule perhaps best describes consumers' evaluation of the elements of CS in terms of repeat purchase behaviour. Although participants are clearly not very satisfied with the CS of certain supermarkets, they still shop there because of the acceptability of certain other attributes such as affordability and location.

The systems theory postulates that changing one element (e.g. store location) can affect the interpretation of other elements of CS (e.g. price). This is supported in the findings; participants confess to patronizing two of the supermarkets of which certain elements of CS are rated as poor and even unacceptable, because they are affordable and conveniently located. When discussed individually, certain elements are thus stressed and strongly debated although they are not necessarily crucial in terms of the final decision to patronise a supermarket or not. CS that encourages repeat purchase behaviour and store loyalty may therefore not necessarily derive from the individual elements of CS that represent excellent CS and service quality, which explains why some of the supermarkets that are severely criticized yet remain in business.

Retailers are advised not to relax when favourable output, good sales and store patronage are achieved. Considering a retailer's objective, namely to attract and attain a competitive advantage and ensure consumers' loyalty, shops should concentrate on feedback (the post-purchase reaction to purchase behaviour), because post-purchase evaluation affects consequent purchases and contributes to the internal frame of reference that determines future evaluation of supermarkets as well as interpersonal communication about CS. If consumers are satisfied with the consequences of a purchase experience, the possibility of repeat purchase behaviour and store loyalty increases. During the focus group discussions, participants mentioned that when they are satisfied they not only patronise a store on a regular basis, but also recommend it to others. Subsequently the contrary also applies; dissatisfaction will probably result in negative word-of-mouth communication and non-purchase behaviour. Participants even said that they explicitly discourage friends and family to visit stores where they experience poor CS. Examples of their responses include the following:

- "I will never recommend anyone to go to $\mathrm{E}$; the store is a mess."

- "I cannot imagine why one would go to E for your shopping if $B$ is just around the corner; I would never recommend one to buy there."

- "I have been to C more than once and I always come out disappointed; I will certainly not recommend anyone to shop there."

An article in a national Sunday newspaper ("Die grootste adverteerders in $2004 ": 2005)$ listed the ten South African companies that spent most on advertising in the country in the 2004 financial year. This list included four of the five supermarket groups included in this study. Interestingly, the group that was rated best in terms of individual CS attributes was not included in the list. Thorough scrutiny of the content of the advertisements shows that these supermarkets emphasise PRICE, though this specific element of CS is not identified as a very important determinant of CS as expected by customers. We can thus suggest that budgets allocated to promotion of price be reallocated to programmes that will enhance the knowledge and competence of personnel, since these were strongly criticized throughout the study.

\section{LIMITATIONS OF THE STUDY}

Because the study was done in an affluent suburb in 
an urban area where all of the popular supermarkets are located in close proximity, it was assumed that these stores would more or less represent the best of what these retailers can provide. The findings do thus not necessarily reflect the situation everywhere in the country.

\section{REFERENCE LIST}

ARENI, CS. 2003. Examining managers' theories of how atmospheric music affects perception, behaviour and financial performance. Journal of Retailing and Consumer Services 10(1):263 -274.

ARNOLD, MJ. 2003. Hedonic shopping motivations. Available online. URL: http://www.sciencedirect.com/ journalofretailing. Accessed 13 October 2002.

ASSAEL, H. 1993. Consumer Behavior and Marketing Action. 5th Edition. London. Inter Thompson.

BABBIE, E \& MOUTON, J. 1998. The Practice of Social Research. South African Edition. Cape Town. Oxford University Press.

BELL, G. 2003. Is our customer service among the world's worst? Succeed: South Africa's Journal of Entrepreneurship and Management May/June:8-11.

BENNETT, R \&. RUNDLE-THIELE, S. 2004. Customer satisfaction should not be the only goal. Journal of Services Marketing 7:514-523.

BELCH, GE \& BELCH, MA. 1998. Advertising and Promotion: An Integrated Marketing Communications Perspective. Boston. Mc Graw-Hill.

BELL, G. 2003. Is our customer service among the world's worst? Succeed: South Africa's Journal of Entrepreneurship and Management May-June:8-11.

BITNER, MJ. 1994. Critical service encounters: the employee's viewpoint. Journal of Marketing 58(1): 95106.

BOOMS, BH \& BITNER, MJ. 1981. Marketing services by managing the environment. Cornell Hotel and Restaurant Administration Quarterly 23(May):3539.

CALIF, N. 2001. Consumer speaking their minds. Fresh Cut 2(1):16-19.

CLOPTON, SW, STODDARD, JE \& CLAY, JW. 2001. Salesperson characteristics affecting customer complaint responses. Journal of Consumer Behaviour 1 (2):124-139.

COOK, WA. 1982. Turning focus groups inside out. Advances in Consumer Research IX:62-65.

CRONIN, JJ, BRADY, MK \& HULT, CTM. 2000. Assessing the effects of quality, value and customer satisfaction on consumer behavioral intentions in service environments. Journal of Retailing 76(2):193-218. DABHOLKAR, P, WESLEY, JJ \& AMY, SC. 1994. The dynamics of long-term business to business exchange relationships. The Journal of the Academy of Marketing Science 22(1):130-145.

DANAHER, PJ. 1997. Using conjoint analysis to determine the relative importance of service attributes measured in customer satisfaction surveys. Journal of Retailing 73(2):235-260.

DAWSON, J. 2000. Retailer power, manufacturer power, competition and some questions of economic analysis. International Journal of Retail and Distribution Management 28(1):5-8.
DIE GROOTSTE ADVERTEERDERS IN 2004. 2005. Rapport 17 April.

DU PLESSIS, PJ, ROUSSEAU, GG \& BLEM, NH. 1995. Consumer Behaviour: A South African Perspective. Pretoria. Sigma.

DU VÁZQUEZA, R, RODRÍGUEZ, D, DÍAZ, D \& RUIZC, S. 2003. Service quality in supermarket retailing: identifying critical service experiences. Journal of Retailing and Consumer Services 8(1):1-14.

ERASMUS, A \& DONOGHUE, S. 1998. Consumer satisfaction: an unattainable ideal? Journal of Family Ecology and Consumer Sciences 26(1):35-39.

ERDEM, O, OUMIL, B \& TUNCALP, S. 1999. Consumer values and the importance of store attributes. International Journal of Retail \& Distribution Management 27(4):137-144.

, MEB, PIERCE, SH, MONROE, PA, SASSER, DD, SHAFFER, AC \& BLALOCK, LB. 1999. Focus group discussions: three examples from family and consumer science research. Family and Consumer Sciences Research Journal 27:428-450.

GOFF, BG, BOLES, JS, BELLENGER, DN \& STOJACK, C. 1997. The influence of salesperson selling behaviors on customer satisfaction with products. Journal of Retailing 73(2):171-183.

GOWAN, M, SEYMOUR, IBARRECHE, S \& LACKEY, C. 2001. Service quality in a public agency: Same expectations but different perceptions by employees, managers, and customers. Journal of quality Management 6(1)275 - 291.

HOLBROOK, MB \& HIRSCHMAN, EC. 1982. The experiential aspects of consumption: consumer fantasies, feelings and fun. Journal of Consumer Research 9(3):132-140.

HOWARDELL, D. 2003. How to improve customer service. Available online. URL: http:// www.acagroup.com. Accessed 18 March 2003.

IACOBUCCI, D, OSTROM, A, \& GRAYSON, K. 1995. Distinguishing service quality and customer satisfaction: the voice of the consumer. Journal of Consumer Psychology 4(3):277-303.

KATZER, J. 1982. Evaluating Information: A Guide for Users of Social Sciences Research. London. AddisonWesley.

KIM, JS, BAIL, MK \& KWON, JH. 2002. A comparison of Korean, Japanese and Chinese consumers' perceptions of the luxury product. Proceedings of the 2002 Multicultural Marketing Conference of the Academy of Marketing Science. Valencia, Spain.

LEONG, SM, HOON, S \& LIN, LH. 1997. Effects of physical environment and locus of control on service evaluation: a replication and extension. Journal of Retailing and Consumer Services 4(4):231-237.

LEVY, M. \& WEITZ, B. 2001. Retailing Management. 4th Edition. New York. McGraw-Hill.

MALAN, N. 2003. Differentiate or die. Succeed: South Africa's Journal of Entrepreneurship and Management (January-February):40-42.

MARSHALL, G \& NIELSON, AC. 2001. South Africa's shopping: questions answered. Progressive Retailing Oct:41-43.

MCQUARRIE, EF \& MCINTYRE, SH. 1988. Conceptual underpinnings for the use of group interviews in consumer research. Advances in Consumer Re- 
search XV:580-586.

MOUTON, J. 1996. Understanding Social Research. Pretoria. Van Schaik.

NEUMAN, WL. 1997. Social Research Methods: Qualitative and Quantitative Approaches. 3rd Edition. London. Allyn \& Bacon.

NIELSEN, AC. 2002. What's hot around the globe? Available online. URL: http://www.acnielsen.com. Accessed 30 July 2001.

PLUG, C, LOUW, DA, GOUWS, LA \& MEYER, WF. 1997. Psigologiese Woordeboek. Johannesburg. McGraw-Hill.

REYNOLDS, KE \& BEATTY, SE. 1999. A relationship customer typology. Journal of Retailing 75(4):509-523. RHEE, H \& BELL, DR. 2002. The inter-store mobility of supermarket shoppers. Journal of Retailing 78 (4):225-237.

SAMSON, HE \& LITTLE, WG. 1993. Retail Merchandising: Consumer Goods and Services. 11th Edition. Cincinnati. South-Western.

SEYBOLD, PB. 2001. Get inside the lives of your customers. Harvard Business Review May:80-90.

SHARMA, A \& LEVY, M. 1995. Categorization of customers by retail sales people. Journal of Retailing 71(1):71-81.

SCHIFFMANN, LG \& KANUK, LL. 2000. Consumer Behavior. 7th Edition. Upper Saddle River, New Jersey.
SOLOMON, M. 1986. The missing link: surrogate consumers in the marketing chain. Journal of Marketing 50(10):208-218.

SPEARS, MC \& GREGOIRE, AG. 2003. Food Service Organizations. 5 th Edition. Upper Saddle River, New Jersey. Pearson.

SPRENG, RA \& MACKOY, RD. 1996. An empirical examination of a model of perceived service quality and satisfaction. Journal of Retailing 72(2):201-214.

THANG, D \& TAN, B. 2003. Linking Consumer Perception to Preference of Retail Stores: An Empirical Assessment of the Multi-Attributes of Store Image. Available online. URL: http://www.sciencedirect.com/ journalofretailingandconsumerservice. Accessed 13 October 2002.

WEBSTER, F. 1994. Defining the new marketing concept. Journal of Marketing Management 2(4):22-32.

WHITCHURCH, GG \& CONSTANTINE, LL. 1993. Systems Theory: Sourcebook of Family Theories and Methods. New York. Plenum.

WINSTEAD, KF. 1997. The service experience in two cultures: A behavioural perspective. Journal of Retailing 73(3):337-360.

WOODRUF, RB 1997. Customers value: the next source for competitive advantage. Journal of the Academy of Marketing Science 25(2):139-153.

ZIKMUND, WG. \& D'AMICO, M. 2001. Marketing: Creating and Keeping Customers in an E-commerce World. 7th Edition. Cincinnati. South Western. 